Original Research Paper

\title{
Penerapan Project Based Learning dengan Pendekatan STEM dalam Upaya Meningkat Kemampuan Menyusun Program CNC Pada Kelas XI Teknik Pemesinan SMK Negeri 3 Mataram
}

\author{
Anwar Muhaimin ${ }^{1^{*}}$ \\ ${ }^{1}$ Sekolah Menengah Kejuruan Negeri 3 Mataram, Indonesia.
}

*Corresponding Author: Anwar Muhaimin, Sekolah Menengah Kejuruan Negeri 3 Mataram, Indonesia, Indonesia

Email:

anwarmuhaimin@yahoo.com

\begin{abstract}
Abstrak: Penelitian ini bertujuan untuk mengetahui pengaruh penerapan pembelajaran project based earning dengan pendekatan STEM terhadap peningkatan kemampuan siswa kelas XI Teknik Pemesinan SMK Negeri 3 Mataram dalam menyusun program CNC pada mata pelajaran Teknik Pemesinan CNC. Penelitian ini merupakan penelitian tindakan kelas dengan menerapkan tiga siklus. Pengukuran kemampuan menyusun program CNC menggunakan empat yaitu kemampuan menyusun kepala program, kemampuan menyusun parameter-parameter pemrograman, kemampuan menyusun kode $\mathrm{G}$ dan kode $\mathrm{M}$, dan kemampuan menyusun addres-address pemrograman. Hasil penelitian menunjukkan bahwa pada indikator menyusun kepala program terdapat $100 \%$ siswa yang mencapai nilai ketuntasan belajar baik pada siklus pra tindakan, siklus I maupun siklus II. Pada indikator menyusun parameter-parameter pemrograman, siswa yang mencapai nilai ketuntasan belajar terdapat $50 \%$ pada siklus pra tindakan, $70 \%$ pada siklus I, dan $95 \%$ pada siklus II. Pada indikator menyusun kode G dan kode $M$, siswa yang mencapai nilai ketuntasan belajar terdapat $15 \%$ pada siklus pra tindakan, $65 \%$ pada siklus I, dan $82 \%$ pada siklus II. Pada indikator menyusun address-address pemrograman, siswa yang mencapai nilai ketuntasan belajar terdapat $0 \%$ pada siklus pra tindakan, $55 \%$ pada siklus I, dan $80 \%$ pada siklus II.
\end{abstract}

Kata Kunci: kemampuan menyusun program CNC; project based learning; STEM.

\section{Pendahuluan}

Science, Technology, Engineering, Mathematics (STEM) merupakan suatu pembelajaran terintegrasi antara sains, teknologi, teknik dan matematika untuk mengembangkan kreativitas siswa melalui pemecahan masalah dalam kehidupan seharihari (Winarni et al., 2016). Penelitianpenelitian pendidikan berkaitan dengan penerapan STEM dalam proses pembelajaran memberikan data bahwa STEM memberikan pengaruh terhadap hasil belajar siswa. Penelitian dalam bidang STEM yang dipublikasikan dalam berbagai jurnal pendidikan dilakukan dengan mengimplementasikan model-model pembelajaran inovatif dalam berbagai disiplin keilmuan.

Rahmizal et al., (2015) melakukan penelitian berkaitan dengan pengembangan Lembar Kerja Siswa (LKS) STEM dalam 
meningkatkan motivasi dan aktivitas belajar peserta didik pada materi induksi elektromagnetik. Analisis data dilakukan dengan chi-square test, dimana hasil analisis data menunjukkan nilai $\chi^{2}$ hitung lebih besar dari $\chi^{2}$ tabel baik pada motivasi belajar maupun aktivitas belajar. Diismpulkan bahwa, LKS STEM mampu menigkatkan motivasi belajar dan aktivitas belajar peserta didik pada materi induksi elektromagnetik. Afriana, J., et.al (2016) melakukan penelitian penerapan Project Based Learning terintegrasi STEM dalam rangka meningkatkan literasi sains siswa ditinjau dari gender. Penilitian melibatkan 57 siswa yang terdiri dari laki-laki (29 orang) dan perempuan (28 orang). Pengumpulan data dilakukan dengan menggunakan tes awal dan tes akhir untuk literasi sains. Berdasarkan hasil analisis data diperoleh peningkatan literasi sains siswa kelompok laki-laki dan kelompok perempuan sama-sama mengalami peningkatan dengan rerata $N$-Gain yaitu 0,36 dan 0,31 pada kategori sedang untuk aspek pengetahuan dan kompetensi. Hasil uji-t menunjukkan bahwa peningkatan literasi sains kelas laki-laki dan kelas perempuan berbeda tidak signifikan. Agustina et al., (2017) dalam penelitiannya mengenai penerapan pembelajaran STEM untuk meningkatkan kemampuan control of variable pada materi Hukum Pascal dilakukan dengan 37 siswa sebagai sampel penelitian. Kemampuan control of variabel merupakan salah satu kemampuan scientific reasoning yang diperlukan selama proses penyelidikan ilmiah. Pengukuran dilakukan dengan menggunakan tes scientific reasoning berbentuk pilihan ganda bertingkat yang diadopsi dari Lawson Classroom Test Scientific Reasoning (LCTSR). Hasil penelitian menunjukkan peningkatan control of variable siswa setelah diterapkan pembelajaran berbasis STEM memiliki n-gain sebesar 0,45 dalam katagori sedang.

Utami et al., (2017) melaksanakan penelitian dalam kaitannya dengan penerapan media animasi melalui pengembangan STEAM-A (Science, Technology, Engineering, Mathematic and Animation) berbasis kearifan lokal dalam pembelajaran Fisika. Melalui analisis dengan n-gain menunjukkan bahwa penggunaan media animasi melalui STEM bengaruh peningkatan penguasaan konsep Fisika. Adelita et al., (2017) melakukan penelitian berkaitan dengan pengembangan strategi pembelajaran dengan pendekatan STEM-Project Based Leaning pada materi laju reaksi. Penelitian melibatkan dua kelompok kelas, yaitu kelas uji coba dan kelas non-uji coba. Penelitian bertujuan untuk menghasilkan strategi pembelajaran pada materi laju reaksi yang valid, praktis dan efektif Adapun perbandingan hasil data test rata-rata kelas ujicoba dan non ujicoba berturut-turut sebesar 83,25 dan 77 . Berdasarkan analisa data, dapat disimpulkan bahwa strategi pembelajaran ini dikategorikan valid, praktis dan efektif. Susanti et al., (2018) melakukan penelitian mengenai penerapan media pembelajaran berbasis STEM pada mata pelajaran Kimia materi reaksi redoks, untuk meningkatkan hasil belajar siswa. Penelitian melibatkan 20 siswa dari Sekolah Menengah Kejuruan dan Sekolah Menengah Atas untuk meneliti keefektifan media. Selanjutnya penelitian dilakukan dengan melibatkan 66 siswa dari Sekolah Menengah Kejuruan dan Sekolah Menengah Atas terhadap kefektifan media terhadap hasil belajar pengetahuan dan sikap. Hasil penelitan menunjukkan bahwa pembelajaran berbasis STEM berpengaruh pada hasil belajar pengetahuan dan sikap siswa.

Penelitian yang dilakukan oleh Muthi'ik et al., (2018) untuk mengetahui efektivitas pendekatan pembelajaran STEM terhadap selfefficacy dan hasil belajar siswa pada Materi Hukum Newton. Berdasarkan penelitian yang telah dilakukan, diperoleh rata-rata n-gain pada selfefficacy dan hasil belajar siswa sebelum dan setelah pembelajaran menggunakan pendekatan STEM. Perolehan rata-rata n-gain pada self-efficacy dan hasil belajar siswa mengalami peningkatan dengan kategori sedang. Hal ini menunjukkan bahwa pendekatan pembelajaran STEM efektif untuk meningkatkan self-efficacy dan hasil belajar 
siswa. Lestari et al., (2018) melakukan penelitian berkaitan dengan implementasi Lembar Kerja Siswa (LKS) dengan pendekatan STEM untuk meningkatkan kemampuan berpikir kritis siswa pada indikator kemapuan evaluasi dan kemampuan interpretasi. Penelitian dilaksanakan dengan metode eksperimen meliputi persiapan, pelaksanaan, dan pengolahan data. Pengumpulan data dilaksanakan menggunakan pretest dan postest selanjutnya dianalisis dengan n-gain. Hasil n-gain menunjukkan bahwa LKS dengan pendekatan STEM meningkatkan kemampuan berpikir kritis siswa dengan n-gain pada kategori medium (0.5). Khoiriyah et al., (2018) melakukan penelitian tentang Implementasi pendekatan pembelajaran STEM untuk meningkatkan kemampuan berpikir kritis siswa SMA pada materi gelombang bunyi. Penelitian dilakukan dengan membandingkan kelas kontrol dan kelas eksperimen. Hasil penelitian menunjukkan bahwa nilai rata-rata $\mathrm{N}$-gain pada kelas eksperimen sebesar 0,63 dan kelas kontrol sebesar 0,35 dengan kategori sedang. Secara keseluruhan implementasi pendekatan pembelajaran STEM mampu meningkatkan kemampuan berpikir kritis siswa.

Ariani et al., (2019) melakukan penelitian berkaitan dengan menganalisis kemampuan berpikir kreatif peserta didikmelalui penerapan model Problem Based Learning berpendekatan STEM pada materi kelarutan dan hasil kali kelarutan (KSP) Pengambilan sampel pada penelitian ini menggunakan teknik purposive sampling. Instrumen pengumpulan data menggunakan metode tes berupa soal uraian berpikir kreatif. Hasil penelitian menunjukkan bahwa kemampuan berpikir kreatif peserta didik setelah diterapkan model Problem Based Learning berpendekatan STEM pada materi KSP berada dalam kriteria baik. Astuti \& Yuliasma (2019) meneliti tentang penerapan model Project Based Learning (PjBL) terintegrasi dengan STEM dalam meningkatkan penguasaan konsep dan aktivitas belajar siswa. Penelitian dilakukan dengan melibatkan 21 peserta didik sebagai sampel penelitian, dengan menggunakan teknik purposive sampling. Hasil analisis data dengan menggunakan uji$Z$, disimpulkan bahwa model Project Based Learning (PjBL) terintegrasi STEM dapat meningkatkan penguasaan konsep dan aktivitas belajar. Penelitian berkaitan dengan bahan ajar berbasis STEM dilakukan oleh Afifah \& Ellianawati (2019) melakukan penelitian berkaitan dengan kemamuan kognitif siswa jika diterapkan pembelajaran dengan menggunaklan bahan ajar berbasis STEM pada materi getaran dan gelombang. Hasil analisis bahan ajar dapat dikategorikan layak dengan persentase 78,46\%. Hasil analisis respon siswa setelah penerapan bahan ajar diperoleh dengan persentase $83,74 \%$ sehingga dapat disimpulkan bahwa bahan ajar yang termasuk dalam kategori sangat praktis digunakan. Hasil analisis profil kognitif pemahaman konsep siswa diperoleh persentase interpretasi sebesar 76,06\%. Sumardiana et al., (2019) melakukan penelitian berkaitan dengan mengukur kemampuan berpikir kritias pada model Project based Learning disertai STEM pada mteri suhu dan kalor. Penelitian dilakukan dengan melibatkan 35 siswa. Hasil penelitian menunjukkan bahwa terdapat perbedaan keterampilan berpikir kritis siswa sebelum dan sesudah mendapatkan perlakuan PjBL pada materi suhu dan kalor. Kemampuan berpikir kritis siswa mengalami peningkatan pada setiap indikator.

Twiningsih (2020) meneliti tentang penggunaan media Magix Box yang diintegrasikan dengan STEM pada pembelajaran konsep Matematika. Penelitian dilakukan menggunakan metode Classroom Action Resarch dengan dua siklus, 27 peserta didik dilibatkan sebagai sampel penelitian. Hasil penelitian menunjukkan bahwa, penggunaan media Magix Box yang diintegrasikan dengan STEM berpengaruh pada peningkatan persentase peserta didik yang mencapai nilai ketuntasan belajar minimal, yaitu dari $70.83 \%$ pada siklus I, menjadi $91.66 \%$ pada siklus II. Sukmaganti et 
al., (2020) melakukan penelitian berkaitan dengan pengembangan Lembar Kerja Siswa berbasis STEM untuk meningkatkan kemampuan berpikir kreatif siswa. Penelitian melibatkan dua kelompok siswa yaitu kelas eksperimen dan kelas kontrol. Berdasarkan hasil analisis N-Gain menunjukkan bahwa LKS berbasis STEM dapat meningkatkan kemampuan berpikir kreatif, yaitu pada aspek kelancaran, keluwesan, elaborasi, dan orisinalitas yang ditandai dengan peningkatan nilai pretest-posttest.

Penelitian-penelitian

diatas

membuktikan efektivtas pembelajaran dengan pendekatan STEM, baik dalam lingkup pengembangan bahan ajar maupun implementasinya dalam proses pembelajaran. STEM yang dikombinasikan dengan model pembelajatan Project Based Learning pada peneliktian-penelitian diatas juga berpengaruh signifikan terhadap peningkatan hasil belajar siswa. Pada penelitian ini, diterapkan model pembelajaran Project Based Leaning dengan pendekatan STEM pada pembelajaran Teknik Pemesinan CNC/NC dalam upaya meningkatkan kemampuan siswa kelas XI Teknik Pemesian (TPM) Sekolah Menengah Kejuruan (SMK) Negeri 3 Mataram dalam menyusun program CNC. Mata Pelajaran Teknik Pemesinan CNC/NC merupakan salah satu mata pelajaran yang disampaikan pada kompetensi keahlian TPM di SMK. Menyusun program CNC merupakan salah satu materi dari pembelajaran ini. Kemampuan menyusun program CNC siswa selama ini masih tergolong rendah. Selama ini, penyusunan program disampaikan melalui pemberian contoh, dilanjutkan dengan pemberian masalah dalam bentuk job sheet untuk diselesaikan. Prosentase jumlah siswa yang mampu menyusun program $\mathrm{CNC}$ dengan benar sebanyak 45\%. Dalam upaya meningkatkan kemampuan siswa dalam menyusun program CNC tersebut, maka perlu diterapkan salah satu solusi yaitu menerapkan model pembelajaran Project Based Leaning dengan pendekatan STEM.

\section{Metode}

Jenis Penelitian ini adalah penelitian tindakan kelas (classroom action research) atau disingkat PTK. Penelitian Tindakan Kelas meliputi empat tahapan yaitu perencanaan tindakan, pelaksanaan tindakan, pengamatan tindakan, dan refleksi. Adapun tahap-tahap penelitian yang dilakukan dapat dilihat pada Gambar 1 berikut.

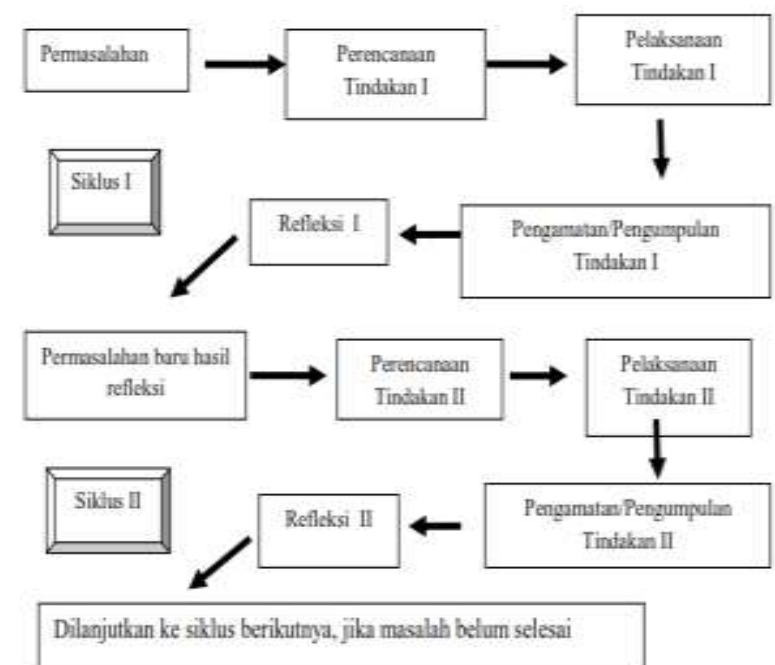

Gambar 1. Diagram Siklus Penelitian Tindakan Kelas (sumber: Arikunto, 2010)

Siklus PTK yang digunakan dalam penelitian ini meliputi tiga siklus yaitu: Siklus Pra Tindakan, Siklus I, dan Siklus II. Data yang kumpulkan dalam penelitian ini adalah kemampuan siswa dalam menyusun program setelah tindakan. Sumber data pada penelitian ini adalah siswa kelas XI Teknik Pemesinan (TPM) SMK Negeri 3 Mataram tahun ajaran 2019/2020 yang berjumlah 31 siswa. Pelaksanaan penelitian dimulai pada bulan September 2019 sampai dengan bulan Oktober 2019. Instrumen dalam penelitian ini adalah penilaian terhadap kemampuan siswa dalam menyusun program CNC. Instrumen penelitian bertujuan untuk mengukur peningkatan kemampuan siswa dalam menyusun program $\mathrm{CNC}$, diukur melalui indikator penyusunan program CNC untuk mesin bubut Kontrol GSK (GSK928Tea, 2014) yang meliputi: (1) penyusunan kepala 
program, (2) penyusunan parameterparameter pemrograman, (3) penyusunan kode $\mathrm{G}$ dan $\mathrm{M}$, dan (4) penyusunan adress $\mathrm{X}, \mathrm{Z}$, $\mathrm{U}, \mathrm{V}, \mathrm{P}, \mathrm{Q}, \mathrm{I}$, dan $\mathrm{K}$, yang diamati setelah dilakukan penerapan model pembelajaran Project Based Leaning dengan pendekatan STEM. Data kemampuan kemampuan menyusun program $\mathrm{CNC}$ diperoleh melalui penilaian hasil pemrograman siswa, meliputi penilaian kemampuan menyusun program CNC pada saat pra tindakan, pada akhir siklus I, dan pada akhir siklus II.

Untuk menguji tingkat signifikasi perbedaan kemampuan menyusun program CNC setiap siklus dilakukan uji perbedaan dua rata-rata melalui uji-t dengan bantuan SPSS 20 for Windows dengan terlebih dahulu dilakukan uji normalitas dan uji homogenitas data.

\section{Hasil dan Pembahasan}

Kemampuan menyusun program $\mathrm{CNC}$ siswa dalam penelitian ini terdiri dari kemampuan menyusun program CNC pra tindakan, kemampuan menyusun program CNC siklus I, dan kemampuan menyusun program CNC siklus II. Kemampuan analisis pra tindakan dilaksanakan sebelum siswa diberikan tindakan. Berdasarkan data penelitian, kemampuan menyusun program CNC siswa kelas XI TPM SMK Negeri 3 Mataram, pada siklus pra tindakan terdapat $100 \%$ siswa yang menunjukkan kemampuan menyusun program CNC pada indikator penyusunan kepala program, 50\% pada indikator penyusunan parameter-parameter pemrograman, $15 \%$ siswa pada penyusunan kode $G$ dan $M$, dan $0 \%$ siswa pada penyusunan adress $\mathrm{X}, \mathrm{Z}, \mathrm{U}, \mathrm{V}, \mathrm{P}, \mathrm{Q}, \mathrm{I}$, dan $\mathrm{K}$.

Implementasi Project Based Leaning dengan pendekatan STEM diterapkan pada siklus I, yaitu dengan menerapkan langkahlangkah Project Based Learning Laboy-Rush (Laboy-Rush D., 2010) meliputi sintak: reflection, research, discovery, application, dan communication. Pada sintak reflection siswa diberi permasalahan berkaitan dengan pembuatan bidak catur menggunakan bahan aluminium, pada sintaks research siswa dikondisikan untuk menentukan standar opreasional prosedur penyusunan program CNC pembuatan bidak catur, pada sintak discovery siswa dikondisikan untuk menyusun program CNC untuk membuat bidak catur, pada sintak application siswa dikondisikan untuk mengoperasikan program CNC pada mesin CNC sampai dihasilkan bidak catur, dan pada sintak communication siswa dikondisikan untuk mempresentasikan hasil. Pada siklus I terdapat $100 \%$ siswa yang menunjukkan kemampuan menyusun program CNC pada indikator penyusunan kepala program, $70 \%$ pada indikator penyusunan parameter-parameter pemrograman, $65 \%$ siswa pada penyusunan kode $G$ dan $M$, dan 55\% siswa pada penyusunan adress $\mathrm{X}, \mathrm{Z}, \mathrm{U}, \mathrm{V}, \mathrm{P}, \mathrm{Q}, \mathrm{I}$, dan $\mathrm{K}$.

Pada Siklus II dilanjutkan implementasi Project Based Learning dengan pendekatan STEM. Kegiatan pada sintak reflection siswa diberi permasalahan berkaitan dengan pembuatan proros bertingkat tirus yang merupakan bagian dari suku cadang mesin menggunakan bahan baja ST-37, pada sintaks research siswa dikondisikan untuk menentukan standar opreasional prosedur penyusunan program CNC pembuatan proros bertingkat tirus, pada sintak discovery siswa dikondisikan untuk menyusun program CNC pembuatan proros bertingkat tirus, pada sintak application siswa dikondisikan untuk mengoperasikan program CNC pada mesin CNC sampai dihasilkan proros bertingkat tirus, dan pada sintak communication siswa dikondisikan untuk mempresentasikan hasil. Pada siklus I terdapat $100 \%$ siswa yang menunjukkan kemampuan menyusun program CNC pada indikator penyusunan kepala program, 95\% pada indikator penyusunan parameterparameter pemrograman, $82 \%$ siswa pada penyusunan kode $\mathrm{G}$ dan $\mathrm{M}$, dan $80 \%$ siswa pada penyusunan adress $\mathrm{X}, \mathrm{Z}, \mathrm{U}, \mathrm{V}, \mathrm{P}, \mathrm{Q}, \mathrm{I}$, dan K. 
. Deskripsi pencapaian nilai kemampuan analisis dan N-gain pada setiap indikator dan Tabel 1. Deskripsi Kemampuan Analisis Siswa

\begin{tabular}{|c|c|c|c|c|c|c|c|}
\hline \multirow{3}{*}{ No } & \multirow{3}{*}{$\begin{array}{l}\text { Indikator Kemampuan } \\
\text { Penyusun Program CNC }\end{array}$} & \multicolumn{6}{|c|}{ Kemampuan Analisis Siswa $(\mathrm{KB}=65)$} \\
\hline & & \multicolumn{2}{|c|}{ Pra Tindakan $(\mathrm{N}=31)$} & \multicolumn{2}{|c|}{ Siklus I $(\mathrm{N}=31)$} & \multicolumn{2}{|c|}{ Siklus II $(\mathrm{N}=31)$} \\
\hline & & $\overline{\bar{X}}$ & SD & $\bar{X}$ & SD & $\bar{X}$ & SD \\
\hline 1 & Penyusunan kepala program & 75,29 & 3,31 & 77,52 & 3,76 & 79,94 & 3,15 \\
\hline 2 & $\begin{array}{l}\text { Penyusunan parameter- } \\
\text { parameter pemrograman }\end{array}$ & 68 & 7,67 & 69,48 & 6,74 & 72,94 & 4,19 \\
\hline 3 & Penyusunan kode $\mathrm{G}$ dan $\mathrm{M}$ & 62,81 & 5,60 & 70,16 & 7,21 & 71,45 & 5,42 \\
\hline 4 & $\begin{array}{l}\text { Penyusunan adress } \mathrm{X}, \mathrm{Z}, \mathrm{U}, \mathrm{V}, \mathrm{P} \text {, } \\
\mathrm{Q}, \mathrm{I} \text {, dan } \mathrm{K}\end{array}$ & 60,4 & 0,9 & 68,39 & 6,21 & 72 & 5,72 \\
\hline
\end{tabular}

Keterangan

KB : Nilai ketuntasan belajar

$\mathrm{N} \quad$ : Jumlah siswa

$\bar{X} \quad$ : Nilai rata-rata kemampuan menyusun program CNC

SD : Standar Deviasi

Uji beda rata-rata terhadap data yang dicantumkan pada Tabel 1 dilakukan terhadap setiap sumber data. Uji beda rata-rata kemampuan menyusun program $\mathrm{CNC}$ siswa pada setiap indikator, antara pra tindakan dengan siklus I diperoleh nilai $t_{\text {hitung }}=-3,705$ dan $t_{\text {tabel }}=1,699$ pada taraf kepercayaan 0,05 pada indikator kemampuan penyusunan kepala program. Karena $t_{\text {hitung }} \leq t_{\text {tabel }}$ maka dapat disimpulkan bahwa tidak terdapat perbedaan yang signifikan terhadap nilai ratarata kemampuan penyusunan kepala program antara pra tindakandengan siklus I. Pada indikator penyusunan parameter-parameter pemrograman diperoleh nilai $t_{\text {hitung }}=-2,986$ dan $t_{\text {tabel }}=1,699$ pada taraf kepercayaan 0,05. Karena $t_{\text {hitung }} \leq t_{\text {tabel }}$ maka dapat disimpulkan bahwa tidak terdapat perbedaan yang signifikan terhadap nilai rata-rata kemampuan penyusunan parameterparameter pemrograman antara pra tindakan dengan siklus I. Pada indikator penyusunan kode $\mathrm{G}$ dan $\mathrm{M}$ diperoleh nilai $t_{\text {hitung }}=6,865$ dan $t_{\text {tabel }}=1,699$ pada taraf kepercayaan 0,05. Karena $t_{\text {hitung }}>t_{\text {tabel }}$ maka dapat disimpulkan bahwa terdapat perbedaan yang signifikan terhadap nilai rata-rata kemampuan penyusunan kode $G$ dan $M$ antara pra tindakan dengan siklus I dimana nilai rata-rata pada siklus I lebih tinggi secara signifikan pada setiap siklus dicantumkan dalam Tabel 1. dibanding nilai rata-rata pada pra tindakan. Sedangkan pada indikator penyusunan adress $\mathrm{X}, \mathrm{Z}, \mathrm{U}, \mathrm{V}, \mathrm{P}, \mathrm{Q}$, I, dan $\mathrm{K}$, diperoleh nilai $t_{\text {hitung }}=7,345$ dan $t_{\text {tabel }}=1,699$ pada taraf kepercayaan 0,05. Karena $t_{\text {hitung }}>t_{\text {tabel }}$ maka dapat disimpulkan bahwa terdapat perbedaan yang signifikan terhadap nilai rata-rata kemampuan penyusunan adress $\mathrm{X}, \mathrm{Z}, \mathrm{U}, \mathrm{V}, \mathrm{P}$, $\mathrm{Q}$, I, dan $\mathrm{K}$ antara pra tindakan dengan siklus I dimana nilai rata-rata pada siklus I lebih tinggi secara signifikan dibanding nilai rata-rata pada pra siklus.

Uji beda rata-rata kemampuan penyusun program CNC pada setiap indikator antara siklus I dengan siklus II diperoleh nilai, $t_{\text {hitung }}=-5,504$ dan $t_{\text {tabel }}=1,699$ pada taraf kepercayaan 0,05 untuk indikator kemampuan penyusunan kepala program. Karena $t_{\text {hitung }} \leq t_{\text {tabel }}$ maka dapat disimpulkan bahwa tidak terdapat perbedaan yang signifikan terhadap nilai rata-rata kemampuan kemampuan penyusunan kepala program antara siklus I dengan siklus II. Pada indikator penyusunan parameter-parameter pemrograman diperoleh nilai $t_{\text {hitung }}=4,007$ dan $t_{\text {tabel }}=1,699$ pada taraf kepercayaan 0,05. Karena $t_{\text {hitung }}>t_{\text {tabel }}$ maka dapat disimpulkan bahwa terdapat perbedaan yang signifikan terhadap nilai rata-rata kemampuan penyusunan 
pemrograman antara siklus I dengan siklus II, dimana nilai rata-rata kemampuan penyusunan parameter-parameter pemrograman pada siklus II lebih tinggi dibandingkan siklus I. Pada indikator penyusunan kode $G$ dan $M$ diperoleh nilai $t_{\text {hitung }}=1,208$ dan $t_{\text {tabel }}=1,699$ pada taraf kepercayaan 0,05. Karena $t_{\text {hitung }} \leq t_{\text {tabel }}$ maka dapat disimpulkan bahwa tidak terdapat perbedaan yang signifikan terhadap nilai ratarata kemampuan penyusunan kode $\mathrm{G}$ dan $\mathrm{M}$ antara siklus I dengan siklus II. Sedangkan pada indikator penyusunan adress $\mathrm{X}, \mathrm{Z}, \mathrm{U}, \mathrm{V}$,
$\mathrm{P}, \mathrm{Q}$, I, dan $\mathrm{K}$, diperoleh nilai $t_{\text {hitung }}=3,775$ dan $t_{\text {tabel }}=1,699$ pada taraf kepercayaan 0,05. Karena $t_{\text {hitung }}>t_{\text {tabel }}$ maka dapat disimpulkan bahwa terdapat perbedaan yang signifikan terhadap nilai rata-rata kemampuan penyusunan adress X, Z, U, V, P, Q, I, dan K antara siklus I dengan siklus II dimana nilai rata-rata pada siklus II lebih tinggi secara signifikan dibanding nilai rata-rata pada siklus I.

Perbandingan nilai rata-rata kemampuan analisis setiap indikator pada setiap siklus ditampilkan dalam Gambar 2.

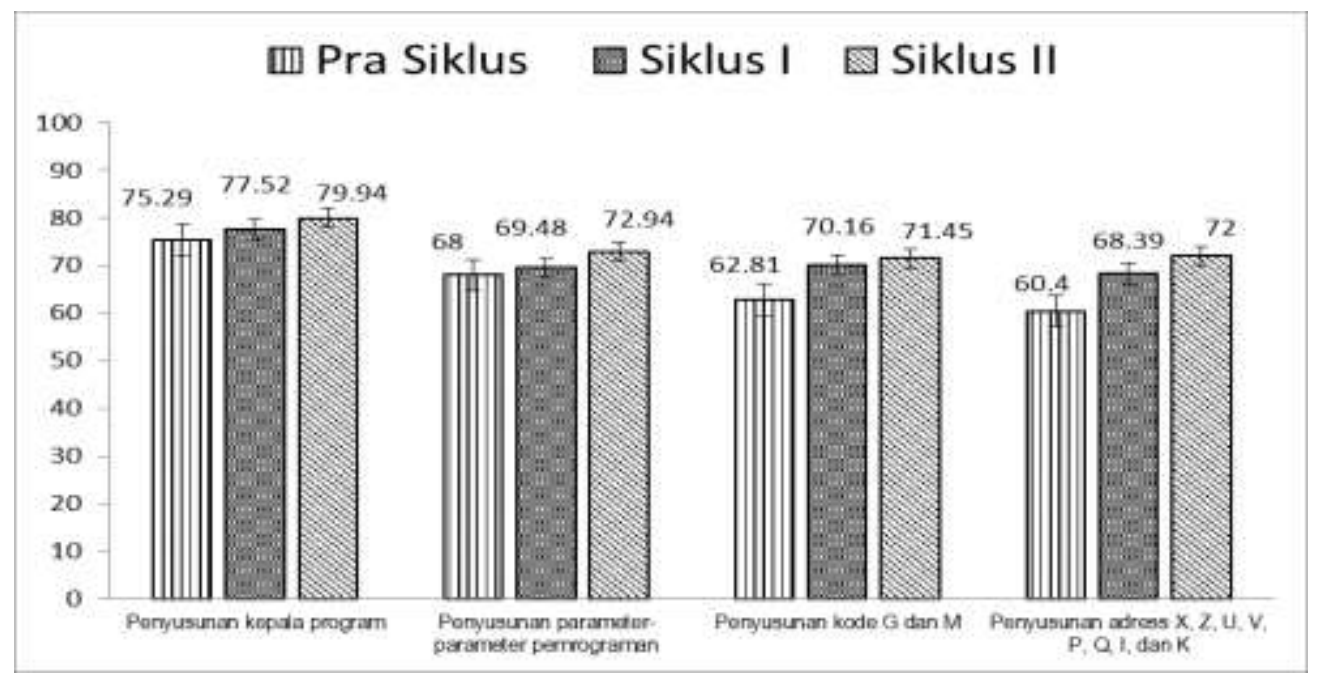

Gambar 2. Perbandingan Pencapaian Nilai Rata-rata Kemampuan Menyusun Program CNC Setiap Indikator pada Setiap Siklus

Indikator kemampuan menyusun kepala program merupakan indikator yang tidak sulit pada proses penyusunan program CNC secara keseluruhan. Pada proses ini, peserta didik diminta untuk menuliskan identitas pahat selanjutnya menentukan koordinat posisi awal pahat. Identitas pahat merupakan identitas tunggal dalam prose pembelajaran Teknik Pemesinan CNC pada mesin bubut di SMK Negeri 3 Mataram. Karena pahat tersebut tunggal, maka identitas pahat akan sangat mudah dipahami oleh siswa. Demikian juga dengan koordinat awal pahat dimana penentuannya ditetapkan pada posisi sembarang dengan memperhatikan posisi pahat terhadap benda kerja. Dengan kriteria ini, maka kemungkinan siswa melakukan kesalahan sangat kecil. Oleh karena itu, penerapan pembelajaran Project Based Learning dengan pendekatan STEM tidak berpengaruh signifikan terhadap indikator kemampuan menyusun kepala program.

Pada indikator kemampuan menyusun parameter-parameter pemrograman tidak terdapat perbedaan yang signifikan antara pra tindakan dengan siklus I. Kemampuan pada indikator ini lebih ditekankan pada analisis jenis bahan terhadap tabel-tabel parameter pemrograman. Untuk menentukan parameterparameter pemrograman, maka pengkondisian pembelajaran yang paling tepat adalah berlatih sesering mungkin dengan menggunakan berbagai jenis bahan yang bervareasi. Dengan berlatih sesering mungkin, 
maka konsep persamaan penentuan parameter pemrograman akan lebih dipahami oleh siswa. Perbedaan kemampuan siswa pada penyusunan parameter pemrograman terliaht pada siklus I dan siklus II. Perbedaan ini disebakan oleh sintak research, discovery, dan application yang berulang dilakukan oleh siswa pada penggunaan persamaan-persamaan matematis dalam menentukan parameterparameter pemrograman.

Untuk indikator kemampuan penyusunan kode $\mathrm{G}$ dan kode $\mathrm{M}$, terhadap perbedaan yang signifikan antara pra tindakan dan siklus I, akan tetapi antara siklus I dan siklus II tidak terdapat perbedaan yang signifikan. Kemampuan penyusunan kode $\mathrm{G}$ dan kode $\mathrm{M}$ merupakan kemampuan menerapkan kodekode pemrograman dalam menentukan bentuk benda kerja. Perbedaan yang signifikan antara para siklus dan siklus I disebabkan karena pemberian project yang lebih menarik sebagai implementasi Project Based Learning. Bidak catur yang ditetapkan sebagai project pada sintaks reflection, memberikan pengaruh terhadap keingintahuan siswa dapat menyusun program. Oleh karena itu, rasa keingintahuan siswa guna menyelesaikan benda kerja sampai terwujud benda jadi, mendorong siswa untuk memahami kodekode $\mathrm{M}$ dan $\mathrm{G}$ tersebut guna diterapkan pada project bidak catur. Sementara itu, tidak terdapat perbedaan yang signifikan antara siklus I dan siklus II pada indikator penyusunan kode $G$ dan kode $M$. Hal ini disebabkan karena penggunaan kode $G$ dan kode $\mathrm{M}$ yang berulang pada project di siklus II. Sehingga, pemahaman siswa yang sudah diperoleh pada saat siklus I, kembali diterapkan pada siklus II.

Pada indikator kemampuan penyusunan address $\mathrm{X}, \mathrm{Z}, \mathrm{U}, \mathrm{V}, \mathrm{P}, \mathrm{Q}, \mathrm{I}$, dan $\mathrm{K}$ terdapat perbedaan yang siginifkan baik antara pra tindakan dengan siklus I, maupun antara siklus I dengan siklu II. Nilai rata-rata siswa pada indikator ini semakin meningkat dari siklus satu ke siklau yang lain. Perbedaan dan peningkatan ini disebabkan karena project bidak catur pada siklus I dan project poros bertingkat tirus pada siklus II merupakan project nyatayang merupakan pendekatan STEM yang didukung dengan informasi dimensi benda kerja yang lengkap. Informasi dimensi dari project yang lengkap ini mendukung kemampuan siswa untuk menentukan address-adress yang diperlukan. Sementara itu, pada addres-addres tertentu merupakan proses yang diulang antara siklus I dan siklus II, sehingga akan mempermudah siswa untuk kembali menentukan penyusunan addres-addres yang diperlukan.

\section{Kesimpulan}

Hasil penelitian menunjukan bahwa penerapan pembelajaran Project Based Leaning dengan pendekatan STEM dapat meningkatkan kemampuan siswa kelas XI Teknik Pemesinan SMK Negeri 3 Mataram dalam kemampuan menyusun program CNC pada mata pelajaran Teknik Pemesinan CNC. Peningkatan ditunjukkan dengan meningkatnya prosentase siswa yang mencapai nilai ketuntasan belajar pada indikator kemampuan menyusun parameterparameter pemrogram, kemampuan menyusun kode $G$ dan kode $M$, serta kemampuan menyusuan addres $\mathrm{X}, \mathrm{Z}, \mathrm{U}, \mathrm{V}, \mathrm{P}$, $\mathrm{Q}$, I, dan K pada akhir siklus pembelajaran. Pengembangan project-project baik ide dari guru maupun ide kolaborasi antara guru dan siswa yang dapat diimplementasikan seiring dengan penyampaian materi-materi pada mata pelajaran Teknik Pemesinan CNC. Pengembangan project akan mempermudah penerapan pendekatan STEM sehingga Project Based Learning dengan pendekatan STEM merupakan salah satu alternatif guna meningkatkan kemampuan peserta didik dalam menyusun pemrograman $\mathrm{CNC}$.

\section{Daftar Pustaka}

Adelita, T., Suhery, T., \& Ibrahim, A.R. (2017). Pengembangan Strategi Pembelajaran dengan Pendekatan STEM - Problem Based Learning pada Materi Laju Reaksi 
di Kelas XI SMA. Jurnal Penelitian Pendidikan Kimia. Kajian Hasil Penelitian Pendidikan Kimia, 4(2).

Afifah, R., \& Ellianawati. (2019). Student Cognitive Profile with STEM Based Teaching Material on the Subject of Vibrations and Waves. JPPPF (Jurnal Penelitian dan Pengembangan Pendidikan Fisika), 5(2).

Afriana, J., Permanasari, A., \& Fitriani, F. (2016). Penerapan Project Based Learning Terintegrasi STEM untuk Meningkatkan Literasi Sains Siswa Ditinjau dari Gender. Jurnal Inovasi Pendidikan IPA, 2 (2): 202 - 212

Agustina, D., Kaniawati, I., \& Suwarma, I.R. (2017). Penerapan Pembelajaran Berbasis STEM (Science, Technology, Engineering and Mathematics) Untuk Meningkatkan Kemampuan Control Of Variable Siswa SMP pada Hukum Pascal. Prosiding Seminar Nasional Fisika (E-Journal) SNF2017, VI(Oktober).

Ariani, L., Sudarmin, \% Nurhayati, S. (2019). Analisis Berpikir Kreatif pada Penerapan Problem Based Learning Berpendekatan STEM. Jurnal Inovasi Pendidikan Kimia, 13(1): 2307 - 2317

Arikunto, S. (2010). Prosedur Penelitian Suatu Pendekatan Praktik. Jakarta: PT Bumi Aksara.

Astuti, I.D, \& Yulisma L. (2019). Model Project Based Learning (Pjbl) Terintegrasi STEM untuk Meningkatkan Penguasaan Konsep dan Aktivitas Belajar Siswa. Quagga: Jurnal Pendidikan dan Biologi pISSN 1907-3089, e-ISSN2651-5869

GSK Control Systam (2014). GSK928TEa Turning CNC System User Manual. GuangZou: GSK Ltd.

Khoiriyah, N., Abdurrahman, \& Wahyudi, I. (2018). Implementasi pendekatan pembelajaran STEM untuk meningkatkan kemampuan berpikir kritis siswa SMA pada Materi Gelombang Bunyi. JRKPF UAD. 5(2).
Laboy-Rush, D. 2010. Integrated STEM Education through Project-Based Learning. Diakses melalui

https:/ / docplayer.net/5787795Integrated-stem-education-throughproject-based-learning.html

Lestari, D.A, Astuti, B., \& Darsono, T. (2018). Implementasi LKS dengan Pendekatan STEM (Science, Technology, Engineering, And Mathematics) untuk Meningkatkan Kemampuan Berpikir Kritis Siswa. Jurnal Pendidikan Fisika dan Teknologi 4(2).

Muthi'ik, I.I, Abdurrahman, \& Rosidin, U. (2018). The Effectiveness of Applying STEM Approach to SelfEfficacy and Student Learning Outcomes for Teaching Newton's Law. JPPPF (Jurnal Penelitian dan Pengembangan Pendidikan Fisika), 4(1).

Rahmiza, S., Adlim, \& Mursal. (2015). Pengembangan LKS STEM (Science, Technology, Engineering, and Mathematics) dalam Meningkatkan Motivasi dan Aktivitas Belajar Siswa SMA Negeri 1 Beutong pada Materi Induksi Elektromagnetik. Jurnal Pendidikan Sains Indonesia, 3(1).

Sukmaganti, O.P., Yulianti, D., \& Sugianto. (2020). Pengembangan Lembar Kerja Siswa (LKS) Berbasis STEM (Science, Technology,Engineering, and Mathematics) untuk Meningkatkan Kemampuan Berpikir Kreatif Siswa. Unnes Physics Education Journal, 9 (1)

Sumardiana, Hidayat, A., \& Parno. (2019). Kemampuan Berpikir Kritis pada Model Project Based Learning disertai STEM Siswa SMA pada Suhu dan Kalor. Jurnal Pendidikan, 4(7): 874-879

Susanti, L.Y, \& Hasanah, R. (2018). Penerapan Media Pembelajaran Kimia Berbasis Science, Technology, Engineering, and Mathematics (STEM) untuk Meningkatkan Hasil Belajar Siswa SMK/SMA pada Materi Reaksi Redoks. Jurnal Pendidikan Sains (JPS) 6(2): 32-40

Twiningsih, A.T. (2020). Improving Student Learning Outcomes through Stem-Based 
Magic Box Medium in The Concept of Addition Theory. International Journal of Research in STEM Education (IJRSE). 2(1): 79-90

Utami, I.S., Septiyanto, R.F., \& Wibowo, F.C. (2017). Pengembangan STEM-A (Science, Technology, Engineering, Mathematic and Animation) Berbasis Kearifan Lokal dalam Pembelajaran Fisika. Jurnal Ilmiah Pendidikan Fisika Al-BiRuN. Volume 06 (1): 67-73 P-

Winarni, J., Zubaidah, S., Supriyono, K.H. (2016). STEM : Apa, Mengapa, dan Bagaimana?. Prosiding Seminar Pendidikan IPA Pascasarjana Universitas Negeri Malang. 1(2016). ISBN: 978-6029286-21-2. 